\title{
Enfrentando o racismo na França e no Brasil: da condenação moral ao auxílio às vítimas ${ }^{1}$
}

\section{Resumo}

A ideia de democracia racial no Brasil e o modelo republicano na França constituem o pano de fundo dos movimentos de composição e de decomposição da questão do racismo praticado nesses dois países. Essa formas consagradas não estão desligadas da maneira como o racismo é representado, assim como da elaboração de imperativos voltados ao seu combate. A reflexão cruzada sobre a evolução das formas de reconhecimento do racismo no Brasil e na França, proposta por este artigo, permite sobretudo revisitar concepções jurídicas, políticas, sociais, assim como a vivência pessoal a elas vinculadas em diferentes períodos. Dos dois lados do Atlântico, os modos de compreensão do racismo têm há muito tempo feito pesar uma espécie de determinismo sobre as vítimas, mantendo-as em parte à distância do problema.

Palavras-chave: Racismo; Vítimas; Vitimização.

\author{
Alexandra Poli \\ Doutora em Sociologia pela \\ L'École des Hautes Études en \\ Sciences Sociales - EHESS - \\ França \\ polialexandra@yahoo.fr
}

\begin{abstract}
Para citar este artigo:
POLI, Alexandra. Enfrentando o racismo na França e no Brasil: da condenação moral ao auxílio às vítimas. Revista Linhas. Florianópolis, v. 16, n. 32, p. $246-285$, set./dez. 2015. Título original: Faire face au racisme en France et au Brésil: de la condamnation morale à l'aide aux victimes. Traduzido por Fernando Coelho, com revisão técnica de lone Ribeiro Valle.
\end{abstract}

DOI: $10.5965 / 1984723816322015246$

http://dx.doi.org/10.5965/1984723816322015246

${ }^{1}$ Tradução de Fernando Coelho e revisão técnica de Ione Ribeiro Valle. 


\title{
Facing racism in France and Brazil: from the moral condemnation to the aid to the victims
}

\begin{abstract}
The Brazilian racial democracy and the French Republican model have determined specific conceptions of racism and different ways to tackle it. Examining racism through these two political contexts leads to raise the question of the link between its legal, political, social and personal definitions. On both sides of the Atlantic, perspectives on racism have made victims passive, keeping them away from the problem. Experiences of racism and racial discriminations have remained in the shadow of history or have melted in the social issue. As time goes by, many great mutations related to the way of thinking differences in Brazil and France have influenced the debate on racism. Public authorities are under increasing pressure to handle the problem and to pay more attention to lived experience of racial discriminations. These evolutions show that the political culture of both countries can no longer contain the fight against racism crossed over global to personal conceptions which challenge the State's action.
\end{abstract}

Keywords: Racism; Victims; Victimization. 
A luta contra o racismo se desenvolveu consideravelmente e se transformou nessas últimas décadas. Influenciada pelo crescimento da mobilização internacional em torno da noção de direitos do Homem², suas orientações e suas realizações se baseiam sobretudo na cultura política nacional na qual ela está inserida. Os debates da última conferência internacional contra o racismo, que aconteceu em 2001 em Durban, são, aliás, testemunhos das dificuldades em encontrar uma linguagem comum sobre a questão em face da heterogeneidade das definições segundo os países e os grupos de indivíduos envolvidos ${ }^{3}$.

Tomemos o caso do Brasil e da França. O mito da democracia racial no Brasil parece ser o oposto do mito francês da República. O primeiro faz da harmonia das relações entre as raças, que seria o fruto das múltiplas mestiçagens que marcaram a história do Brasil, um pilar da democracia. Essa narrativa, construída progressivamente desde a abolição da escravatura, não deixa muito espaço para o reconhecimento do racismo, cuja própria existência é com frequência posta em dúvida ${ }^{4}$. A parte do racismo e o modo como ele se manifesta na sociedade permanecem ainda mal definidos em um país em que quase $45 \%$ da população é negra 5 .

O mito republicano francês, impregnado do espírito lluminista, preconiza o afastamento de todo particularismo cultural a fim de assegurar o tratamento igualitário dos cidadãos. Os princípios republicanos garantem uma vigilância e uma condenação rigorosas do racismo, ao mesmo tempo em que limitam o debate sobre as próprias categorias que o fenômeno põe em jogo. A impossibilidade de levar em conta as diferenças fundadas na origem, na etnia, ou na religião nas estatísticas limita a produção de uma visão de conjunto e condiciona o reconhecimento das discriminações raciais.

\footnotetext{
${ }^{2}$ Boli J., Thomas G., « World Culture in the World Polity: A Century of International Non-Governmental Organisation ", American Sociological Review, n 62, 1997, pp. 171-190.

3 Os delegados da conferência, por exemplo, recusaram o credenciamento de uma organização nãogovernamental, a Associação Internacional dos Homossexuais e Lésbicas, enquanto a União Europeia e outros países defenderam sua participação em nome da não-discriminação. «La Conférence Mondiale contre le racisme est mal partie», Le Monde, 4 août 2001.

${ }^{4}$ Esse tema é central na análise dos especialistas do racismo, mas também na literatura brasileira. A obra do dramaturgo Nelson Rodrigues está marcada por esta questão e denuncia o que se esconde atrás das aparências ao colocar o dedo sobre uma farsa da qual com certa frequência se orgulham os brasileiros, a saber, a crença de que no Brasil se vive em uma democracia racial. Rodrigues N., L'ange noir, Paris, Collection des Quatre-vents, 1988 (1947).

${ }^{5}$ Como indica o último Censo do IBGE (os negros são os que se autodeclaram negros ou "pardos"). Ver o seguinte link: www.ibge.gov.br.
} 
Esse pano de fundo, próprio de cada país, nos dá uma primeira ideia das dificuldades de medir o racismo e combatê-lo. Ele permite, entre outros, melhor compreender a natureza da defasagem que se observa no Brasil e na França entre o desenvolvimento de uma legislação, decorrente de diversos recursos jurídicos para lutar contra o racismo e as discriminações, e sua aplicação. Esses instrumentos podem, com efeito, permanecer relativamente ignorados pelas instituições, assim como pelos indivíduos que deveriam fazer uso deles.

Dos dois lados do Atlântico, os modos de compreensão do racismo levaram a uma espécie de determinismo sobre as vítimas, que de diversas maneiras manteve-as à distância do problema. A experiência vivida pelas vítimas ficou por muito tempo na sombra dos dramas e das feridas do passado, ou ainda da questão social. A ajuda direta às vítimas implica, com efeito, o reconhecimento de uma atualidade problemática das discriminações raciais, que coloca em questão o funcionamento profundo da sociedade, de suas instituições, e que corre o risco de ameaçar as bases de sua tradição democrática.

Com o passar do tempo, as grandes mutações que se verificam no interior dessas duas sociedades moldaram um novo olhar sobre o racismo e sobre as discriminações raciais, levando a opinião pública a se interessar cada vez mais pelos indivíduos que são vítimas deles. Em particular, a vitalidade das afirmações identitárias étnicas, culturais e religiosas, observáveis no Brasil e na França, confere uma nova densidade à questão do racismo.

Da denúncia de uma experiência vivida à responsabilização, as grandes etapas da ação antirracista nos dois países revelam os processos de construção e de desconstrução do tabu que envolvem o reconhecimento do racismo, amplamente influenciados pela sua cultura política nacional. Hoje, as antigas bases normativas já não são suficientes para conter a luta contra o racismo, que se desencadeia num espaço atravessado por múltiplas linhas de tensão, erguendo-se do global ao pessoal, e lançam um desafio à ação do Estado nesse domínio. 


\section{Dos pensamentos racistas à denúncia do racismo}

A mobilização internacional que nasce logo após a Segunda Guerra Mundial pela criação das Nações Unidas coloca no centro de sua reflexão a luta contra o racismo. Os autores da Carta das Nações Unidas enunciam nesse documento histórico que cada um, sem distinção de cor, sexo, língua ou religião, pode fazer valer os direitos do Homem e das liberdades fundamentais. Este engajamento tomado em nível internacional é parte de uma transição histórica determinante que leva os Estados a se apropriarem da questão da raça, das relações inter-raciais e do racismo, como mostram os exemplos francês e brasileiro. O debate, contudo, não é o mesmo nos dois países, ainda que o desafio seja acima de tudo o de contornar ou anular as doutrinas e as ideologias racistas que devem tornar-se tabus. Um primeiro esforço consiste em questionar as concepções científicas sobre a raça, cuja remodelagem deve marcar a ruptura com o antigo sistema racial.

O labirinto de relações entre a ideia de raça e de racismo

A descoberta dos horrores nazistas na Europa e depois os movimentos de descolonização dos anos 1950 abalam os fundamentos do racismo científico e tornam indispensável o seu desmonte. Profundas mutações atingem portanto a utilização do conceito de "raça", cujo uso se torna cada vez mais constrangedor. A desconstrução dos postulados científicos aos quais ele por muito tempo serviu toma vias distintas segundo os países.

Na sociologia americana dos anos 1950, o trabalho de Park, inspirado na tradição teórica do interacionismo simbólico, marca uma virada decisiva ao elaborar a noção de "raça" como uma categoria social, simbolicamente constituída, emergindo das relações entre grupos ${ }^{6}$. Essa perspectiva contrasta, na verdade, com a teoria da assimilação dos negros que prevalece até então na sociologia da Escola de Chicago. A questão racial passa a se referir às situações de conflito e de competição entre grupos, interpretadas pelos atores sociais em termos de "raça". Essa nova abordagem permite, aliás, o distanciamento das variadas formas de reducionismo psicológico ou biológico que o

\footnotetext{
${ }^{6}$ Park R.E., Race and Culture, New York, The Free Press, 1950.
} 
conceito implica. "As relações raciais [precisa Park] não são tanto as relações entre indivíduos de raças diferentes, mas entre indivíduos conscientes dessas diferenças"”.

O desafio é, portanto, jogar com o significado e a interpretação do termo mais do que com a existência do fenômeno. Essa análise exerceu uma influência fundamental na conceituação da ideia de "raça" no mundo anglo-americano.

Em outros países, como a França, a condenação do racismo científico não procede dessa dissociação. O termo permanece, com efeito, amplamente impregnado pelas ideologias que inspirou, à medida que carrega o reconhecimento de diferenças entre os indivíduos, o que vai ao encontro do espírito da República ${ }^{8}$. Isso leva a diluí-lo na ideia de que as raças não existem e a fazer do seu uso uma afirmação racista.

No Brasil, o debate toma outra forma. Em meados do século XX, a escravidão, abolida apenas em 1888, ainda impregna amplamente as relações sociais. Ademais, em plena construção democrática, o Estado deve justificar décadas de estratégias demográficas racistas (ideologia do branqueamento) que fizeram da mestiçagem da população sua especificidade. A política voluntária de purificação da raça, decidida pelas elites políticas e intelectuais ao longo de todo o século XIX, é refundada em uma reflexão e uma ação de ordem simbólica que tende a glorificar a mestiçagem ${ }^{9}$. Praticamente no mesmo sentido que nos Estados Unidos e na Inglaterra, refunda-se a ideia de raça em novas concepções sem rejeitá-la totalmente. Assim como no Brasil, a diferenciação entre os indivíduos se funda na cor, que, embora conserve um significado fenotípico, essencialista, se relaciona à pele, ao tipo de cabelo, à forma do nariz e da boca, inscrevendo-se igualmente no seu estatuto social ${ }^{10}$. Esses reajustamentos traduzem, em

\footnotetext{
${ }^{7}$ lbid, p. 81.

8 Entretanto, não se trata de introduzir ou defender uma oposição entre aplicação dos princípios republicanos e etnicização ou reconhecimento das diferenças. Catherine Rassiguier revela uma imagem mais problemática e nuançada do modelo francês de integração, colocando em evidência as contradições concernentes ao tratamento da mulher imigrante na história do código da nacionalidade. Esta autora mostra o movimento de fechamento das fronteiras nacionais e de etnicização dos membros nacionais que inspiraram as ondas de imigração no após-guerra e pós-coloniais, assim como a crise econômica dos anos 1970 na Europa. Através das mudanças no código da nacionalidade em 1927, 1945 e 1973, que afetam as mulheres em geral e as mulheres estrangeiras em particular, Rassiguier mostra que os processos de exclusão e de etnicização mudaram ao longo do tempo mas estão longe de ser anomalias no centro da tradição republicana, eles são de fato constitutivos dessa tradição. Ver Rassiguier C., "Gender, Race and Exclusion: A New look at the French Republican Tradition”, International Feminist Journal of Politics, vol. 1, $\mathrm{n}^{\circ}$ 3, 1999, pp. 435-457.

${ }_{9}^{9}$ Bennassar B., Marin R., Histoire du Brésil, 1500-2000, Paris, Fayard, 2000.

${ }^{10}$ Nogueira O., Tanto Preto Quanto Branco: Estudos de Relações Raciais, São Paulo, T.A. Queiroz, 1985.
} 
todo caso, a vontade de canalizar, de circundar a noção de raça e de dissociá-la do racismo.

\section{O envoltório mítico das concepções de racismo}

A ideia de democracia racial no Brasil e o modelo republicano na França constituem o pano de fundo dos movimentos de composição e decomposição da questão do racismo nos dois países. Essas fórmulas consagradas condicionam de certa maneira a existência do racismo e moldam imperativos distintos para combatê-lo. O quadro normativo no qual elas inscrevem a harmonia entre os indivíduos na sociedade se reveste de um caráter mítico pelo fato de fundar-se numa narrativa idealizada das relações sociais. As expressões "país dos direitos do Homem" e "terra da mistura das raças" garantem a unidade do povo e excluem de saída a existência do racismo. Contudo, de um ideal a atingir ao que passa por adquirido, do mito à realidade, as fronteiras se confundem ou, ao contrário, se enrijecem, criando um jogo de sombras e de luzes sobre a questão do racismo.

\section{A harmonia entre as raças, pilar da sociedade brasileira}

No Brasil, a concepção mítica de um país sem discriminação racial está enraizada em uma tradição do pensamento intelectual e político sobre a mestiçagem. Já nos debates conduzidos pelos abolicionistas, a estigmatização ligada à escravidão era bem mais compreendia e criticada como sintoma da exploração social do que apreendida como destino racial ${ }^{11}$. Mas é sobretudo no meio intelectual dos anos 1930 que a ideia da harmonia entre as raças irá se fortalecer, prestando-se à construção de uma identidade nacional $^{12}$. Os três séculos de condição colonial, a persistência do código da escravatura e o impacto da ideologia do branqueamento colocam, de fato, a formação da nação brasileira e a identidade do povo brasileiro num questionamento permanente. As ideias advindas da corrente literária modernista do início do século XX em torno desse tema

\footnotetext{
${ }^{11}$ Azevedo C.M.M. de, " Abolicionismo e memória das relações raciais », Estudos Afro-Asiáticos, 26, 1994, pp. 5-20.

12 Maio M.C., "O Projeto Unesco e A Agenda das Ciências Sociais no Brasil dos Anos 40 e 50 ", Revista Brasileira de Ciências Sociais, vol. 14, n41, 1999, pp. 141-158.
} 
refletem o esforço para encontrar respostas na invenção de uma nova identidade nacional, emancipada dos modelos europeus. ${ }^{13}$ A obra pioneira de Mário de Andrade, Macunaíma, este "herói sem nenhum caráter" em busca do seu talismã perdido, é uma alegoria do Brasil em busca de uma identidade. Ao longo de inúmeros deslocamentos geográficos, linguísticos, ritualísticos e culturais, que se cruzam por toda a narrativa, as aventuras desse personagem celebram a mistura das raças e o sincretismo da cultura brasileira ${ }^{14}$. O povo brasileiro é plural, compósito e, apesar de tudo, unido para constituir uma única e mesma nação. Esse movimento de pensamento encontra sua forma mais bem acabada nas teorias do antropólogo Gilberto Freyre por meio da expressão "democracia racial" 15 .

Como enfatiza Antônio Sérgio Guimarães, Freyre fala inicialmente de democracia social e étnica para marcar o caráter positivo da mestiçagem da população. A reflexão repousa no fato de que os colonos portugueses, ao praticarem uniões com as populações indígenas, favoreceram desde o início a produção de uma sociedade multirracial. Mais ainda, ele define as relações sociais como metarraciais, ou seja, funcionando para além do conceito da raça em razão de uma cultura religiosa comum (a cristandade), e portanto de uma fraternidade que dá lugar a um sincretismo com as religiões africanas centradas na festa $^{16}$. Ao fazer da mistura das raças a particularidade da democracia social no país, Freyre tende a naturalizar o fenômeno e a converter as consequências das lógicas racistas em princípio social positivo. Segundo ele, a intimidade das relações entre o senhor e o escravo, que existe há gerações, acaba por anular qualquer forma de racismo. Além disso, a mestiçagem da população é erigida em indicador da tolerância entre os indivíduos. Assim, essa construção intelectual tende a apagar o caráter racista da ideologia do branqueamento e impede no presente e no futuro um balizamento potencial do problema. Como enfatizam Bastide e Fernandes, o movimento negro dos anos 1930 não se distancia muito dessa tendência ao denunciar a exclusão social como uma

\footnotetext{
${ }^{13}$ Pereira de Queiroz M.I., « Identidade cultural, identidade nacional no Brasil, Tempo Social », Revista de Sociologia da USP, vol. 1, $n^{\circ} 1,1989$.

${ }^{14}$ Andrade M. de, Macounaima, Paris, Stock/Unesco/Allca XX, 1996 (1928).

${ }^{15}$ Freyre G., Casa Grande e Senzala: formação da Família Brasileira sob o regime da economia patriarcal, Rio de Janeiro, Maia \& Schmidt, 1933.

${ }^{16}$ Guimarães A.-S.-A., « Démocratie raciale », Cahiers du Brésil Contemporain, Paris, n 49-50, 2002, pp. 11-38.
} 
consequência da falta de instrução e dos costumes arcaicos da população negra ${ }^{17}$. Não há, portanto, vítimas do racismo, mas do "preconceito de cor" sobre o qual pesa a ideia de que os negros sofrem, sobretudo, as consequências do baixo nível de educação.

Num primeiro momento, o desafio para o Brasil é constituir uma sociedade democrática moderna e desenvolver uma identidade na qual se inscreve implicitamente a ideia de que o racismo não pode existir. Ainda que se trate, aqui, de uma construção intelectual, de uma narrativa, essa visão se funda no imaginário nacional e em fatos, permanecendo baixa a mobilização contra o racismo. Contrastando consideravelmente com o desastre da Europa, a ideia de democracia racial fascina cada vez mais e oferece razões para esperar uma melhor forma de civilização ${ }^{18}$. O movimento negro funda suas reivindicações essencialmente no registro da exploração social e permanece relativamente distante da questão racial. A narrativa da democracia racial enraíza-se assim cada vez mais no real, produzido por uma linguagem de precaução e de justificação em torno do bom entendimento natural entre as raças, mantendo a categorização racial em uma concepção positiva. Essas ideias foram amplamente difundidas durante o período do Estado Novo (1937-1945), o regime autoritário de Vargas. Nos anos 1940, Donald Pierson mostra que os conflitos na Bahia tomam a forma, sobretudo, de antagonismos de classes e não de antagonismos raciais, e sublinha que existe uma tendência a ver um conflito racial em situações em que, na realidade, o que está em jogo ${ }^{19}$ é a competição entre classes. O problema não é, portanto, compreender as relações de poder e de desigualdade em termos de diferença racial, mas antes considerá-las como o produto das relações entre classes.

A categorização racial, fundada na cor, aparece somente mais tarde, à medida que é determinada pela situação social dos indivíduos. O "branco" e o "negro" correspondem a posições socioeconômicas, a tal ponto que a mobilidade ascendente redefine a cor da pele do indivíduo. Eis por que, como observa Pierson, "branco" remete a uma pessoa branca, mas independentemente da sua origem racial, incluindo todos aqueles que, mestiços ou negros, pertencem às classes superiores. A designação "preto" se refere

\footnotetext{
17 Bastide R., Fernandes F., Relações Raciais entre Negros e Brancos em São Paulo, São Paulo, UnescoAnhembi, 1955.

${ }^{18}$ Ver especialmente o livro de Zweig S., Le Brésil, terre d'avenir, Paris, L’Aube, 1992, (1941).

19 Pierson D., Negroes in Brazil: A Study of Race Contact in Brazil, Carbondale, Southern Illinois University Press, 1942.
} 
tanto a traços físicos, quanto ao fato de possuir um baixo estatuto social. Isso não impede que a mobilidade social seja baixa e que os negros permaneçam em sua maioria embaixo na escala social.

Com o tempo, a leitura social das relações raciais se reforça por razões ao mesmo tempo de ordem política e ideológica. Na segunda metade dos anos 1940, Gilberto Freyre consolida o mito da democracia racial ao colocar a mestiçagem como a garantia da unidade do povo brasileiro. Num contexto político internacional ainda sacudido pelo fascismo, ele aproveita a oportunidade para moldar uma expressão democrática inédita, demarcando valores ocidentais e opondo-se às concepções defendidas pelo movimento da negritude. Paralelamente, os estudos em ciências sociais, amplamente influenciados pelo paradigma da luta de classes, insistem sobre o caráter social das desigualdades.

O mito da democracia racial, que valoriza as diferenças que resultam da mestiçagem, se insere numa perspectiva universalizante. Ele opera uma dissociação entre uma dimensão racial idealizada e uma dimensão social percebida como a causa do preconceito de cor sentido pela população negra. As ciências sociais, impregnadas à época pelo pensamento marxista, mas igualmente preocupadas em se distanciar das doutrinas raciais, abundam nesse sentido. Em 1957, Bastide insiste no fato de que não existe no Brasil consciência de raça, nem vontade dos negros de progredir coletivamente $^{20}$. As conclusões da vasta enquete fomentada pela UNESCO no início dos anos 1950 sobre a questão racial (para a qual, aliás, Bastide contribuiu) enfatizam a vontade de se livrar do tabu ligado ao problema racial, historicamente determinado pela colonização e pela escravidão. Os analistas mobilizados para esta pesquisa aparecem amplamente guiados pela ideologia da democracia racial. Sem anular a existência do preconceito racial, e mais precisamente do preconceito de cor, eles desenvolvem uma palheta bastante ampla de constatações que revela suas preocupações ao falar de racismo. Nas conclusões da enquete desenvolvida no Brasil rural e no Nordeste, Bastide (1957, p. 536) afirma:

\footnotetext{
${ }^{20}$ Bastide R., « Les relations raciales au Brésil », Bulletin International des Sciences Sociales, Unesco, vol. 9, $\mathrm{n}^{\circ}$ 4, 1957, pp. 525-543.
} 
O preconceito racial existe no Brasil (...) mas ele se distingue do dos Estados Unidos, porque não discrimina os indivíduos segundo suas origens étnicas, mas segundo sua aparência física - o que faz com que a cor possa ser compensada por outras vantagens, econômicas, por exemplo. (...) Mas hoje praticamente não existem preconceitos; se a cor conta, certamente, na classificação dos indivíduos, uma posição social elevada é capaz de eliminar seus efeitos. A discriminação, por outro lado, existe, mas ela é tanto social e econômica, quanto racial.

A reflexão que se organiza na época em torno da questão racial explicita a vontade de fazer emergir a problemática das discriminações raciais, mas apresenta-a dominada e contida no pensamento da luta de classes e da ideologia da democracia racial. Essa perspectiva, ao que tudo indica, não deixa muito espaço às reivindicações identitárias do movimento negro. O debate se polariza nesse período sobre a existência ou não do "preconceito racial", ou, dito de outra forma, sobre a fronteira entre imaginário e real da democracia racial. Até os anos 1960 no Brasil, o que estava em jogo não era questionar a ideia de democracia racial, mas situar o racismo em relação a ela, o que dá ao fenômeno um caráter relativamente negligenciável.

Contudo, as posições começam a se endurecer com o tempo, e diversas vozes se levantam para denunciar a farsa do que alguns qualificam desde então como "mito da democracia racial", apresentado como um instrumento a serviço da supremacia branca. Florestan Fernandes denuncia a manipulação da democracia racial como um liame dinâmico dos mecanismos de defesa da "raça dominante" dissimulando atitudes, comportamentos e ideais "aristocráticos" 21 . A democracia racial aparece então como o berço ideológico das discriminações sofridas pelos negros e mestiços, os quais poderiam tê-la explorado para seus próprios fins. Entretanto, essa crítica do princípio de igualdade entre as raças é abafada pelo advento da ditadura, que decreta nos atos institucionais de 1964 "a proibição social de falar do racismo"22.

\footnotetext{
${ }^{21}$ Fernandes F., A Integração do Negro na Sociedade de Classes, 3ạ edição, São Paulo, Ática, 1978; Fernandes F., The Negro in Brazilian Society, New York, Columbia University Press, 1969.

${ }^{22}$ Bradford Burns E., A History of Brazil, $3^{\text {ème }}$ édition, New York, Columbia University Press, 1993.
} 
O modelo republicano de integração: do mito como garantia que garante a luta contra o racismo à injunção da integração

Na França, o mito democrático que influencia as concepções do racismo parece muito distante do contexto brasileiro. O período do pós-guerra mergulha o país numa transição histórica atormentada pelo paradigma do genocídio judeu. Se no Brasil o debate situa-se essencialmente no nível intelectual, na França ele se desenvolve sobretudo num terreno político e social. A luta contra o racismo consiste principalmente em colocar nos textos constitucionais a noção de direitos do Homem. Impregnada pelo espírito republicano, a condenação do racismo passa por um processo de marginalização dos particularismos culturais, étnicos e religiosos no espaço público. A harmonia no interior da sociedade repousa assim sobre um princípio de igualdade condicionado pelo ideal do apagamento das diferenças. Na mesma direção da declaração dos direitos do Homem e do cidadão de 1979, a Constituição de 4 de outubro de 1958 estipula em seu artigo primeiro que "a França é uma República indivisível, laica, democrática e social. Ela assegura a igualdade diante da lei de todos os cidadãos sem distinção de origem, de raça ou de religião. Ela respeita todas as crenças".

No aspecto social, diversas associações, tais como a Liga Internacional contra o Racismo e o Antissemitismo (LICRA), a Liga dos Direitos do Homem e o Movimento contra o Racismo e pela Amizade dos Povos (MRAP) se constituem ou desenvolvem a sua ação no contexto da resistência ao nazismo. No período do pós-guerra, essas associações se apresentam como outras tantas células de vigilância para salvaguardar as liberdades individuais e o respeito à dignidade humana. Ao mesmo tempo, a descolonização “desgeografiza” em parte a questão do racismo. A Liga dos Direitos do Homem se dedica, por exemplo, aos problemas ligados à descolonização e às atitudes repressivas e atentatórias aos direitos do Homem da IV e V Repúblicas nas colônias.

Após esse período, marcado pelo genocídio de milhões de judeus, as ondas de imigração dos anos 1960 e 1970, assim como o episódio da guerra da Argélia, vão progressivamente transformar o espaço do racismo. Nos momentos seguintes à Segunda Guerra Mundial, o recurso à imigração se torna um objetivo político prioritário para os poderes públicos: é preciso, por um lado, aumentar o volume da população ativa para a reconstrução, e, por outro, organizar uma imigração de povoamento para compensar o 
déficit demográfico. A figura do imigrado enquanto vítima real ou potencial do racismo aparece unicamente no espaço público através de episódios pontuais e espetaculares. Tal é em especial o caso da efervescência racista de 1973 que Yvan Gastaut considera como o fenômeno em que os franceses foram confrontados pela primeira vez desde o entreguerras com a imigração como um fenômeno negativo. Além das consequências da crise econômica de 1972, essa efervescência racista seria "uma forma de rancor ligado à guerra da Argélia, manifestado em uma parte da opinião"23. Através do eco das mídias e da imprensa, o racismo desvelado de alguns franceses se torna um verdadeiro problema social. Ainda que não se possa reduzir a questão do racismo às consequências da guerra da Argélia, as campanhas racistas ocorridas desde o fim das hostilidades fazem do trabalhador imigrado argelino o principal alvo do racismo. Os acontecimentos marcantes que se estendem ao longo dos anos 1970 - fala-se de atentados racistas - são relacionados às sequelas do colonialismo, a uma "violência neocolonialista contra os imigrados" ${ }^{24}$.

Benjamin Stora considera assim que "os magrebinos, principalmente os argelinos na França, podem ser ainda mais objetos de repulsa quando lembram, pela sua presença, a última guerra que a França fez (e perdeu), causa de uma ferida nacional jamais cicatrizada" 25 .

No plano das políticas públicas, a imigração remete à necessidade de mão de obra para o país, o que a define antes de tudo como uma questão socioeconômica. Diversas instituições especializadas são criadas para ajudar os imigrantes e melhorar suas condições de vida, como o Fundo de Ação Social (FAS) em $1958^{26}$. Em contraste com a situação britânica, em que a questão da imigração remete à questão das diferenças raciais e religiosas dos antigos colonizados, a França considera antes de tudo o fenômeno em termos de mão de obra.

\footnotetext{
${ }^{23}$ Gastaut Y., « Le racisme anti-maghrébin et les séquelles de la guerre d'Algérie », Hommes et Migrations, $\mathrm{n}^{\circ}$ 1174, mars 1994, pp. 35-42.

${ }^{24}$ Weber J., « Racisme pas d'âge », L'humanité, 17 octobre 1978.

${ }^{25}$ Stora B., Le transfert d'une mémoire. De "l'Algérie française » au racisme anti-arabe, Paris, La découverte, 1999, p. 91.

${ }^{26}$ Por uma portaria de 29 de dezembro de 1958, o FAS é definido como um fundo destinado a promover uma ação social e familiar em favor dos assalariados que trabalham na França metropolitana nas profissões visadas pelo regime argelino de alocações familiares e cujos filhos residem na Argélia.
} 
Na virada do mês de julho de 1974, a supressão oficial da imigração na França ${ }^{27}$ põe fim à demanda de mão de obra que caracterizava e justificava a vinda e a presença de populações estrangeiras. A mutação que acontece na passagem de uma imigração de mão de obra, percebida como provisória, a uma imigração definitiva, familiar e de povoamento se torna uma questão maior na cena política e possibilita os primeiros discursos sobre a "necessária integração" dos interessados e de seus descendentes. Em 1976, o governo decide reconhecer aos estrangeiros instalados legalmente na França o direito ao reagrupamento familiar.

Ao mesmo tempo, aparecem manifestações pontuais e espetaculares de racismo contra essas populações. Segundo Gastaut, o paralelo é estreito entre a midiatização da imigração e a interrogação sobre o racismo em prática na sociedade francesa. A questão “Nós somos racistas?” é regularmente apresentada à opinião entre 1970 e $1983^{28}$. Foi em especial entre 1970 e 1973 que esta interrogação se intensificou em torno de acontecimentos dramáticos caracterizados por fatos corriqueiros e por um aumento da violência contra os imigrados. A ligação com a guerra da Argélia é indubitável. Em 1971, depois que o governo argelino decidiu nacionalizar suas companhias petrolíferas, uma violenta campanha anti-imigrados se desenvolve. Em 1973, uma explosão, reivindicada por um movimento de extrema direita, composto por antigos membros da OAS, devasta o consulado da Argélia em Marselha ${ }^{29}$. Os acontecimentos que se estendem ao longo dos anos 1970 traduzem a passagem de um racismo colonial a um racismo antimagrebino, que, mesmo amparando-se nas consequências da crise econômica, se nutre dos rancores relativos à guerra da Argélia $^{30}$.

No início dos anos 1980, o aumento do desemprego e as crises urbanas põem em relevo a precariedade da coesão social e da marginalização da juventude oriunda da imigração. Incidentes nas zonas urbanas com problemas, onde se concentram as populações imigradas, fortemente midiatizados, levaram "a prioridade da antiga ação

\footnotetext{
${ }^{27}$ Nesse ano o governo francês decide suspender a imigração de trabalhadores e de suas famílias nos moldes anteriormente adotados. Essa suspensão permaneceu até 1977, salvo para os que faziam parte da comunidade européia. (N.T.)

${ }^{28}$ Gastaut Y., « 'Sommes nous racistes ?’ Evolution d'une question angoissante dans l'espace public français ", Migrations Société, vol. 9, n 49, janvier-février 1997, pp. 53-66.

${ }^{29}$ Gastaut Y., «La flambée raciste de 1973 en France », Revue Européenne des Migrations Internationales, vol. 9, $\mathrm{n}^{\circ}$ 2, 1993, pp. 61-75.

${ }^{30}$ Gastaut Y., « Le racisme anti-maghrébin et les séquelles de la guerre d’Algérie », Hommes et Migrations, $\mathrm{n}^{\circ}$ 1174, mars 1994, pp. 35-42.
} 
pública a se focar nos lugares habitacionais" ${ }^{31}$. É tão comum a problemática da insegurança urbana e da delinquência entrar no debate sobre a imigração, agrupando numa só expressão os imigrantes e sua descendência, quanto certos discursos como os da Frente Nacional responsabilizá-los por todos os males da sociedade.

Em 1983, um movimento liderado pelos jovens da segunda geração confronta-se fortemente com essas confusões articulando a denúncia do racismo à hipocrisia do modelo de integração. Em 1983, a "marcha pela igualdade e contra o racismo" (também chamada de "marcha dos beurs ${ }^{32}$ ) é a ocasião de mostrar a inconsistência das promessas da República no que concerne aos descendentes de imigrantes magrebinos. Os pais são apresentados como as vítimas passivas de um racismo que as novas gerações apelam para que olhem de frente a partir daí e façam valer o direito à diferença.

Ao longo dos anos 1980, desenvolve-se no espaço público francês o tema do aumento do racismo. Em 1985, a criação da associação SOS racismo promoverá uma midiatização crescente da questão. Essa nova força antirracista, à qual se juntam Radio Beur, France Plus e algumas outras, distancia-se dos canais mais tradicionais da luta contra o racismo ao afirmar a implicação de toda uma geração que se organiza num primeiro momento em torno do debate sobre o direito à diferença.

Essa tendência faz surgir um movimento de "vitimização positiva" que consiste em fazer do racismo uma questão de sociedade, construindo uma nova imagem dos jovens da segunda geração determinados a tomar a palavra, a granjear uma visibilidade no espaço público colocando em primeiro plano o multiculturalismo e a mestiçagem da França. E mais, trata-se de pôr em dúvida as representações relativas à igualdade dos direitos tais como ínsitas nos princípios republicanos ${ }^{33}$.

Contudo, se a questão do racismo é revisitada mais uma vez por essas novas reivindicações, o movimento que lhes é associado se desintegra progressivamente e o

\footnotetext{
${ }^{31}$ Weil P., La France et ses étrangers, l'aventure d'une politique de l'immigration, 1938-1991, Paris, CalmannLévy, 1991.

32 Jovens nascidos na França filhos de pais magrebinos imigrados. (N.T.)

${ }^{33}$ Harlem Désir entrevistado por Pierre-Yves Le Priol, « Gaffe aux récupérations », La Croix, 15, junho de 1985 , declare: "Penso que existe um verdadeiro problema do racismo na França e que não basta gritar para combatê-lo: 'igualdade dos direitos' em todo lugar. Não se pode abolir esse racismo por decreto nem por simples medida igualitária. Eu acredito antes num trabalho a fazer sobre as mentalidades. Veja os antilhanos ou os jovens 'beurs' franceses: eles têm teoricamente os mesmos direitos que os metropolitanos e apesar disso sofrem do racismo."
} 
debate limita-se rapidamente ao problema da imigração. A luta contra o racismo continua, certamente, no plano associativo, sobretudo pelo viés do SOS racismo, mas se posiciona do lado do tema da integração e se desliga da questão da identidade. Ao longo dos anos 1980, os atores políticos e associativos definem as tensões racistas como a manifestação dos problemas sociais nos bairros de exclusão. A questão social é portanto determinante e coloca os indivíduos, vítimas ou autores do racismo, na mesma equação das dificuldades em viver juntos nas periferias.

Assim, existe menos vítimas do racismo do que vítimas das desigualdades sociais, o que leva, inversamente, a vislumbrar a integração socioeconômica dos indivíduos como o fim do racismo. No fundo, além das razões estruturais invocadas, como o desemprego, a insalubridade do hábitat, o principal culpado identificado sem rodeios é a Frente Nacional, cujos escores a tornam cada vez mais ameaçadora, no final dos anos 1980. Esses resultados inquietantes levam a luta contra o racismo nos anos 1990 a fazer do partido seu principal inimigo.

No plano das pesquisas acadêmicas, a questão da vivência do racismo não aparece senão ocasionalmente no quadro dos trabalhos referentes às formas de exclusão ${ }^{34}$ e à vida nos bairros populares, articulada a diversas problemáticas tais como a violência, o islamismo, a escola etc. A questão do racismo aparece com mais frequência de maneira implícita nas análises sobre o universo da periferia, cujas expressões se multiplicam. Os "bairros de exílio"35 são o contexto das manifestações do racismo, frequentemente descrito como o último pilar no qual "os pequenos brancos" se apoiam e sobre o qual vêm se cristalizar percepções de insegurança múltiplas e entremeadas, colocando-se do lado dos racistas ou dos que são o seu alvo.

\footnotetext{
${ }^{34}$ Dubet F., La Galère: jeunes en survie, Paris, Fayard, 1987.

${ }^{35}$ Dubet F., Lapeyronnie D., Les quartiers d'exil, Paris, Seuil, 1992.
} 


\section{A luta contra o racismo nos moldes dos mitos: o racismo à sombra da questão social}

Apesar do surgimento de novas reivindicações que vêm denunciar a falsidade ou a hipocrisia dos mitos, as políticas públicas francesa e brasileira permanecem ancoradas, num primeiro momento, nesses quadros normativos para definir o combate contra o racismo. No Brasil, o final dos anos 1980 marca, entretanto, um passo decisivo no reconhecimento do racismo através da sua criminalização. Ao mesmo tempo, insiste-se na força da narrativa da democracia racial no imaginário coletivo, o que traduz uma tensão entre o reforço do dispositivo legal e as lógicas pessoais e sociais, ou ainda entre o nível político e o nível das práticas.

O racismo existe se ninguém o reconhece como tal?

Os movimentos políticos negros brasileiros que ressurgem no final dos anos 1970 recorrem ao tema da falsidade do mito da democracia racial, defendido por Florestan Fernandes desde meados dos anos 1960. Igualmente, uma nova geração de pesquisadores põe em evidência o modo como algumas formas de discriminações raciais estruturam as desigualdades ${ }^{36}$. Ao longo dos anos 1980, "o mito da democracia racial" é sistematicamente denunciado como um dogma da "supremacia branca" 37 . Fundado em 18 de junho de 1978 em São Paulo, o Movimento Negro Unificado (MNU) denuncia a manipulação da cultura negra assim como as lógicas estatais que fazem do negro um subcidadão. Essas duas reivindicações traduzem, aliás, as tendências atuais que caracterizam o movimento negro, compartilhado de maneira clássica entre uma sensibilidade igualitária, portadora de demandas de discriminação positiva em face da população negra, e uma sensibilidade mais culturalista ${ }^{38}$. Ainda que a influência desses movimentos tenha sido frequentemente questionada pela constatação dominante da

\footnotetext{
${ }^{36}$ Hasenbalg C., Discriminação e desigualdades no Brasil, Rio de Janeiro, Graal, 1979 ; Nelson do Valle S., « Updating the cost of not being white ", in Fontaine M. (dir.), Race, class and power in Brazil, Los Angeles, University of California Press, 1985, pp. 42-55.

37 Guimarães A.-S.-A., «Intelectuais negros e formas de integração nacional », Estudos Avançados, vol. 18, $\mathrm{n}^{\circ}$ 50, 2004, pp. 271-284.

${ }^{38}$ Peralva A., Violence et démocratie. Le paradoxe brésilien, Paris, Balland, 2001, p. 33.
} 
falta de protesto dos afro-brasileiros ${ }^{39}$, suas demandas representam um elemento essencial do pano de fundo sobre o qual se renova a reflexão acerca dos termos do pertencimento nacional ${ }^{40}$.

Os anos 1980 marcam uma mudança real na abordagem das questões étnicas e raciais pelas autoridades brasileiras. Com exceção de uma lei de 1951 que punia a discriminação racial, não existe até então um verdadeiro corpus legislativo para lutar contra o racismo. Ademais, a implementação das leis frequentemente permanece suspensa, dado que a polícia recebe muito poucas queixas, e que há poucos processos sobre questões de racismo ou de discriminação racial. Segundo o Ministro da Justiça, o racismo se manifestaria frequentemente mais por ataques verbais ou injúrias que não levaria a denuncias. Eccles nota, aliás, que entre 1951 e 1991, apenas três casos foram apresentados à justiça tendo por motivo essa lei ${ }^{41}$. Quando o direito penal é acionado, a prova é difícil de administrar, e assim se procura reparar o dano moral sofrido pela vítima, daí a inclusão na Constituição de 1988 do crime "por ofensa ou delito moral de racismo" ou "por dano moral". A mutação essencial, impulsionada pelo governo, consiste então em criminalizar o racismo. Além desse reforço da legislação, outra contribuição relevante da Constituição de 1988 é a restituição pelo Estado dos títulos respectivos de propriedade aos descendentes das comunidades quilombolas, que designavam na época escravagista os agrupamentos de escravos em fuga. Essa disposição constitucional integra uma vontade política de redefinir a identidade brasileira. Ao reconhecer uma comunidade cujas práticas culturais foram por muito tempo objeto de discriminações, o Estado repara

\footnotetext{
39 Hanchard M.-G., Orpheus and Power: the movimento negro of Rio de Janeiro and São Paulo, Brazil, 19451988, Princeton, Princeton University Press, 1994; Skidmore T.-E., " Fact and Myth: discovering a racial problem in Brazil, São Paulo », Instituto de Estudos Avançados, 1992; Telles E.-E., « Ethnic boundaries and political mobilisation among African Brazilians: comparisons with the US case ", in Hanchard M. (dir.), Racial Politics in Contemporary Brazil, London, Duke University Press, 1999; Winant H., « Rethinking Race in Brazil », Journal of Latin American Studies, $n^{\circ} 24,1992$, pp. 173-192; Burdick J., « The lost constituency of Brazil's black movements ", Latin American Perspectives, 25 (1), 1998, pp. 136-155.

${ }^{40}$ Ver os trabalhos de d'Agier, Sansone ou Guimarães, que analisam o surgimento de um "mundo negro" por meio da redescoberta e da valorização das "raízes" africanas, da etnicização das práticas culturais ou da construção de uma territorialidade afro-brasileira. Esses autores sublinham, contudo, o caráter parcial, localizado e fragmentado dessas expressões, que têm dificuldades em se estruturar em um movimento político perene no curso dos anos 1990. Ver Agier M., «Ethnopolitique. Racisme, statuts et mouvement noir à Bahia ", Cahiers d'Etudes Africaines, n' 125, 1992, pp. 53-81; Sansone L., From Africa to Afro, Use and Abuse of Africa in Brazil, the South-South Exchange Programme for Research on the History of Development (SEPHIS) and the Council for the Development of Social Science Research in Africa (CODESRIA), Amsterdam/Dakar, 1999; Guimarães A.-S.-A., Racismo e Anti-racismo no Brasil, São Paulo, Editora 34, 1999.

${ }^{41}$ Eccles P., Culpados até prova em contrário: os negros, a lei e os direitos humanos no Brasil, Estudos Afroasiáticos, 1991.
} 
publicamente séculos de esquecimento e de negação de uma história que ignorava o papel ativo da população negra na construção da nação brasileira ${ }^{42}$.

Assim como na França, esses dispositivos legais, constitucionais, são certamente ferramentas indispensáveis para lutar contra o racismo, mas tendem também a colocar o Estado como garantidor de uma sociedade sem discriminação, protegendo-o também de uma potencial responsabilidade nos mecanismos atuais de produção do racismo. Na verdade, lê-se no primeiro capítulo da Constituição de 1988 que o Brasil "constitui um Estado democrático de direito [que] tem como fundamentos (...) a dignidade da pessoa humana. (...)" (artigo primeiro); "Os objetivos fundamentais [do Brasil] são os seguintes: I. Construir uma sociedade livre, justa e solidária; (...) III. Erradicar a pobreza e a marginalização e reduzir as desigualdades sociais e regionais; IV. Promover o bem de todos, sem preconceitos de origem, de raça, de sexo, de cor, de idade ou qualquer outra forma de discriminação" (artigo $3^{\circ}$ ); 0 artigo 5 da Constituição estipula ademais: "A lei pune toda discriminação que atente contra os direitos e liberdades fundamentais" (parágrafo XLI); “A prática do racismo constitui uma infração imprescritível e pela qual não será admitida liberação sob fiança, ela implica uma pena de reclusão segundo os termos da lei" (parágrafo XLII) ${ }^{43}$.

Nos anos 1990, observa-se um aumento considerável do número de medidas e dispositivos institucionais para lutar contra o racismo ${ }^{44}$. Em São Paulo, por iniciativa do Estado federado, um comissariado contra o crime racista antinegro e antissemita é criado. A prática do testing se desenvolve, ainda que, como na França, o direito não a reconheça como prova. O Estado implementa igualmente uma secretaria nacional para a defesa do cidadão que se encarrega das medidas de luta contra o racismo, sobretudo contra os negros e os judeus ${ }^{45}$.

\footnotetext{
${ }^{42}$ Véran J.-F., «Brésil: les découvertes du « quilombo ». La construction hétérogène d'une question nationale », Problèmes d'Amérique Latine, $n^{\circ}$ 32, 1999.

${ }^{43}$ Edição atualizada em 1994 [texto de 5 de outubro de 1988 modificado pelas emendas n $1 / 92$ a $4 / 93$ e $n^{\circ}$ $1 / 94$ à 6/94], tradução francesa de J. Villemain, atualizada J.F. Cleaver, Brasília, Senado Federal, 1994.

${ }^{44}$ Guimarães A.-S.-A., Racial Inequalities, Black Protest and Public Policies in Brazil, Paper prepared for the United Nations Research Institute for Social Development (UNRISD) Conference on Racism and Public Policy, septembre 2001, Durban, Afrique du Sud.

45 Essas informações foram tiradas do relatório de Maurice Glèlè-Ahanhanzo, relator especial sobre as formas contemporâneas de racismo, de discriminação racial, de xenofobia e da intolerância que Ihe é associada, sobre a missão que realizou no Brasil de 6 a 17 de junho de 1995, em conformidade com as
} 
Essas prerrogativas constituem um avanço importante em matéria de luta contra o racismo. Contudo, resta saber se os indivíduos envolvidos lançam mão delas. Se elas traduzem o questionamento do caráter efetivo da democracia racial pelas políticas, elas são frequentemente apresentadas em defasagem com o imaginário social. Diversos estudos enfatizam, com efeito, as dificuldades em reconhecer a existência do racismo na sociedade. A pertinência da questão é incessantemente levantada por inúmeras enquetes, sondagens, que insistem sobre a diferença que ela suscita, e até mesmo a recusa em lhe dar importância. France Winddance Twine observa que para muitos afrobrasileiros de Vasalia, onde ela desenvolveu sua pesquisa, o racismo não existe na medida em que a maior parte das desigualdades raciais não são percebidas ou sentidas como tais $^{46}$. Como conclusão do estudo, que a leva a enfatizar o desinteresse dos indivíduos em relação ao racismo, ela sublinha a distância entre as medidas tomadas pela ação antirracista, as concepções dos pesquisadores e as dos membros da comunidade afrobrasileira. A partir de uma análise da construção das classificações raciais do Censo, Edward E. Telles sublinha a arbitrariedade e, sobretudo, a instabilidade das identificações raciais conforme seu estabelecimento pelos pesquisadores ou pesquisados ${ }^{47}$.

A partir dos anos $1870^{48}$, exceto durante o período do regime militar, o Instituto Brasileiro de Geografia e Estatística (IBGE) introduziu a dimensão racial no Censo da população. A partir de 1980, pediu-se aos indivíduos que auto declarassem a partir de três categorias pré-definidas, a saber, "branco", "preto" e "pardo"49. Isso se baseia na sondagem do Jornal Folha de São Paulo, realizada em 1995, que faz aparecer pela primeira vez a resposta do pesquisador e do pesquisado sobre a cor da pele, para mostrar que os pesquisadores têm tendência a "branquear" a população, tendo como base particularmente os recursos socioeconômicos e o nível de estudos dos pesquisados.

resoluções 1993/20 e 1995/12 da comissão dos direitos do Homem, Conselho Econômico e Social das Nações Unidas, 23 de janeiro de 1995.

${ }^{46}$ Winddance Twine F., " Mapping the terrain of Brazilian racism », Race and Class, vol. 38, $n^{\circ}$ 3, 1997, pp. 4961.

47 Telles E.-E., Lim N., « Does it Matter Who Answers the Race Question?: Racial Classification and Income Inequality in Brazil ", Demography, 35(4), 1998, pp. 465-474. Ver também do mesmo autor, Racismo à brasileira: uma nova perspectiva sociológica, Rio de Janeiro, Relume-Dumará, Fundação Ford, 2003.

${ }^{48}$ No período imperial, para as atividades estatísticas, o Brasil contava apenas com a Diretoria Geral de Estatística, criada em 1871. Esta diretoria foi substituída pelo Instituto Nacional de Estatística (INE) em 1934. O INE passou a se chamar Instituto Brasileiro de Geografia e Estatística (IBGE), em 1937, quando foi criado o Conselho Brasileiro de Geografia que o incorporou. (N.T.)

49 Nobles M., Shades of Citizenship: Race and the Census in Modern Politics, Stanford, Stanford University Press, 2000. 
Segundo Robin Sheriff, esse tipo de práticas traduz a "hipervalorização" do fato de ser branco no Brasil ${ }^{50}$. Nada coloca em questão o fato de que os negros não precisam ser "branqueados" desde que sejam exitosos socialmente, nem mesmo as declarações dos indivíduos. E assim os agentes do Censo definem como brancos $20 \%$ dos indivíduos que por sua vez se identificam com o grupo de pardos e dispõem em média de rendas superiores às que são geralmente classificadas nessa categoria. Isso sublinha a importância do estatuto social na categorização por cor elaborada pelos pesquisadores quando essas duas variáveis estão com mais frequência por eles dissociadas. Esta constatação o leva a demonstrar que a classificação feita do ponto de vista dos que respondem constitui uma base de dados pertinente para compreender as formas de reivindicação identitária, ao passo que a feita pelos pesquisadores permite pôr ênfase nas desigualdades raciais. Resta saber como, além das interações entre as duas variáveis, o racismo é vivido pelos indivíduos.

As cifras da sondagem encomendada pelo Jornal Folha de São Paulo em 1995 mostram que, se $89 \%$ dos brasileiros pensam que há racismo na sociedade, somente $10 \%$ deles afirmam ser discriminados ${ }^{51}$. Segundo o mesmo estudo, 48\% dos negros entrevistados concordam com a ideia de que "os bons negros têm uma alma branca", o que é revelador das dificuldades de mobilização contra o racismo. Esse fenômeno leva, aliás, uma parte do movimento negro a pôr ênfase na necessidade de desenvolver a educação contra o racismo. Contudo, como sublinha Robin Sheriff, tem-se frequentemente a tendência no Brasil de confundir o silêncio dos indivíduos sobre a questão com o fato de que eles não têm consciência, sobretudo em razão da influência da narrativa da democracia racial ${ }^{52}$. Através de suas enquetes, Sheriff mostra que o problema diz respeito menos ao reconhecimento da existência do racismo do que ao fato de não se falar dele. Esse silêncio socialmente compartilhado - que implica que não se fala da questão nem na esfera privada, nem na esfera pública - se compreende pelo que ele chama de censura cultural, ou seja, uma série de comportamentos, de práticas e de

\footnotetext{
50 Sheriff R., Dreaming Equality: Color, Race, and Racism in Urban Brazil, New Brunswick, Rutgers University Press, 2001, p. 142.

51 Disparidades importantes devem ser destacadas, segundo as regiões. $17 \%$ das pessoas entrevistadas no Nordeste afirmam sofrer discriminações em razão da sua cor, contra 8\% no Sudeste.

52 Sheriff R., « Exposing Silence as Cultural Censorship: A Brazilian Case », American Anthropologist, vol. 102, $\mathrm{n}^{\circ} 1,2000$, pp. 114-132.
} 
crenças (como a de pensar que o fato de falar do racismo corre o risco de exacerbá-lo) que o tornam não problemático.

Em que medida se pode dizer que a vivência das discriminações raciais supõe identificar-se ou ser considerado como pertencente à categoria "preto", ou mesmo “pardo”, e em que medida se transcende esta classificação? É aí que uma confusão se instala no surgimento da figura das vítimas do racismo. Como sublinha Angelina Peralva, “o racismo é vivido como uma experiência complexa e multidimensional, com duas faces principais: a de uma definição negativa do negro (a face racial) e a de uma definição negativa do favelado (a face social)" ${ }^{53}$, sendo essas duas definições complementares e quase indissociáveis. Assim, a partir do momento em que o estatuto social predomina e influencia a designação racial dos indivíduos, o racismo diz respeito unicamente aos indivíduos que são negros ou pardos e excluídos socialmente? Peter Henri Fry lembra a esse respeito que a miríade de categorias de cor também tem uma função. Ela dissipa a eventual polarização racial e as tensões. Esta perspectiva acaba por definir as formas de discriminação racial a partir de critérios econômicos e sociais e igualmente a limitar o combate contra o racismo a uma série de medidas para lutar contra a pobreza.

Enquanto na França o racismo é considerado como uma espécie de vírus, de sintoma, provocado pelo desemprego e pela degradação das condições sociais, a leitura racial da questão social no Brasil leva com mais frequência a apontar as desigualdades entre as raças mais como um estado do social do que como discriminação raciais. Dito de outra maneira, a dimensão racial é somente um efeito ou uma variável e não uma causa dos problemas sociais encontrados pelos indivíduos. Seja na França, em que o racismo não é considerado senão como uma consequência dos problemas sociais, ou no Brasil, em que ele é sem cessar revisto e corrigido pela dimensão social, o fenômeno não aparece senão em uma segunda leitura, ou é até mesmo contornado. No fundo, o reconhecimento do racismo é fundido no molde dos mitos democráticos nos dois países. Nesse quadro, a designação das vítimas do racismo permanece vaga e instável.

A França admite mais facilmente a existência do racismo, mas resiste a levar em conta as mutações que se realizam em torno da afirmação das diferenças. O Brasil dispõe, por sua vez, de dados raciais que permitem fazer aparecer as desigualdades entre as

\footnotetext{
${ }^{53}$ Peralva A., Violence et démocratie. Le paradoxe brésilien, op. cit., p. 53.
} 
raças, mas se concentra essencialmente no seu caráter social, em grande parte em razão dos sistemas de conversão que se operam entre a cor da pele e o estatuto social. A mestiçagem oferece certamente uma possibilidade de jogar com as categorias raciais, mas a polarização racial - e os pressupostos biológicos sobre os quais ela repousa coloca essa capacidade sob pressão ${ }^{54}$. Por outro lado, as referências à mestiçagem não servem às mesmas interpretações. Elas podem estar, com efeito, tanto a serviço de uma ideologia que justifica algumas formas de dominação social nas camadas sociais superiores, quanto da reivindicação implícita de uma comunidade humana. A denúncia do racismo nem sempre leva a uma forma de politização do problema. No Brasil a maior tensão parece se situar entre a lógica de criminalização do racismo e a falta de mobilização dos afro-brasileiros. Na França, a tensão acontece entre a lógica de integração das populações imigradas e de seus descendentes e a lógica de denúncia do racismo.

\section{Rumo a novas formas de reconhecimento: os mitos em debate}

Nesses últimos anos, a mudança mais importante nas concepções do racismo vem do fato de que a experiência vivida pela vítima representa uma questão fundamental para a expressão e o reconhecimento da discriminação racial. Em muitos países, diversos dispositivos institucionais encorajam, com efeito, as vítimas a se manifestarem a fim de melhorar concretamente sua situação. Igualmente, os estudos sobre o racismo e sobre as discriminações se interessam cada vez mais do ponto de vista dos atores diretamente envolvidos. Doravante, o racismo é apreendido como um processo produzido de maneira rotineira e reforçado por meio das práticas do cotidiano. É nessa perspectiva que uma parte das pesquisas apreende o fenômeno em termos de everyday racism (racismo no cotidiano), ao se interessar pelo modo como os indivíduos percebem, vivem e combatem as discriminações raciais.

Nos anos 1990, ocorre uma virada na literatura anglo-americana sobre o racismo, cujo tema central se reorienta para a questão da vivência da discriminação racial. Como sublinham Joe Feagin e Melvin Sikes, “o racismo moderno deve ser interpretado como

\footnotetext{
54 Agier M., Anthropologie du carnaval. La ville, la fête et l'Afrique à Bahia, Marseille, éditions Parenthèses/IRD, 2000, p. 228.
} 
uma experiência vivida (...) As experiências discriminatórias são não somente dolorosas e angustiantes de imediato e nas suas consequências, mas têm também um impacto cumulativo sobre os indivíduos particulares, sua família e sua comunidade (...) O impacto cumulativo de situações de hostilidade racial repetidas é mais prejudicial do que a soma dessas experiências pode parecer para o observador habituado (...) A experiência repetida de formas de racismo afeta de modo significativo o comportamento e a abordagem da existência de uma pessoa negra" 55 .

As questões que derivam dessa perspectiva se situam sobretudo no terreno da necessidade do reconhecimento. Uma vez que a situação socioeconômica dos indivíduos não determina tudo, como encontrar políticas que permitam assegurar o reconhecimento do racismo em uma sociedade a não ser jogando com as suas fontes sociais? É a partir dessa questão que as interrogações sobre os quadros normativos dos dois países aparecem progressivamente.

Da integração socioeconômica como resposta ao racismo à integração cultural como exigência de reconhecimento das discriminações sociais

Até o final dos anos 1990, as medidas para combater o racismo na França não se inserem senão superficialmente na agenda pública que permanece dominada pelo tema condutor da integração. Em 1989, é criado o Alto Conselho para a Integração, cujos trabalhos versam essencialmente sobre os perigos das tendências ao comunitarismo. Em 1991, células governamentais de coordenação da luta contra o racismo são experimentadas em algumas regiões francesas para em seguida serem generalizadas nos conselhos de prevenção da delinquência de cada região a partir de 1993. Esse projeto convidava os governadores a colocar pelo menos uma vez por mês a luta contra o racismo na ordem do dia desse conselho, o que mostra a marginalidade desse tema comparativamente à permanência do tema das violências urbanas nos debates políticos e nas mídias ${ }^{56}$. Sempre acontece que a figura da vítima do racismo se alterna na maior parte do tempo com a do delinquente ou a da recusa da integração cultural (quando elas não se

\footnotetext{
${ }^{55}$ Feagin J., Sikes M., Living with racism, Boston, Beacon, 1994, pp. 15-17.

${ }^{56}$ Peralva A., Macé E., Médias et violences urbaines. Débats politiques et construction journalistique, Paris, La Documentation française, 2002.
} 
confundem). A imagem dos jovens das periferias, eivada pela associação entre imigração e delinquência, tende a deformar e a distanciá-los da realidade vivida das discriminações raciais ${ }^{57}$. A partir dessa articulação, as políticas públicas colocaram em dúvida a integração cultural das populações imigradas e de sua descendência, fazendo pesar sobre elas o fardo do projeto integração. É nesse quadro que se falou a partir de meados dos anos 1980, tanto no discurso acadêmico quanto nas mídias e no discurso político, da ideia e da expressão de uma "crise do modelo de integração".

De modo geral, é menos sobre as figuras das vítimas do que sobre as dos autores do racismo que se fixa a atenção. Ao longo das eleições dos anos 1990, os escores em progressão da Frente Nacional levam o debate a se polarizar sobre essa questão. A subida da extrema direita participou da tensão, ou mesmo do recusa, da sociedade em ver a diversidade das culturas e das identidades que estão presentes nela e em perpétua transformação. Os primeiros grandes debates públicos sobre o uso do véu que aparecem em 1989 em torno das jovens secundaristas de Creil fazem surgir versões caricaturais e intransigentes do modelo republicano de integração. A associação SOS racismo que se opõe à exclusão das jovens é então acusada de defender "o direito à diferença". Essa interpretação pelas mídias e por muitos políticos, intelectuais, tanto de esquerda quanto de direita, desencadeia uma polêmica sobre o antirracismo, em grande parte associado ao nome do SOS racismo, que põe em dúvida a eficácia da sua ação ${ }^{58}$. Ao se pronunciar contra a guerra do Golfo, a associação perde numerosos apoiadores ${ }^{59}$.

Ao longo dos anos 1990, o racismo é relacionado principalmente aos fenômenos que condensam a ideia de exclusão, se impondo desde então nos debates intelectuais e

\footnotetext{
57 «Os imigrados somente aparecem nos jornais em caso de desgraça (...). Pouco a pouco se opera uma espécie de associação no espírito das pessoas entre ‘imigrado' e 'problema' (...). As mídias provavelmente involuntariamente participaram para instaurar um imenso mal-entendido entre os imigrados e a França (...), mas (...) a integração se faz na sociedade, e quanto mais ela se torna irreversível, mais a resistência dos que recusam a realidade é violenta. O que dá medo não é a diferença, mas a semelhança. E isso raramente aparece nas mídias", in M'scope, “Image de l'immigration dans les médias", dossier, 1993, pp. 33-44. Para uma leitura crítica sobre a acumulação das denuncias feitas ao jovem árabe de periferia, ver igualmente Guénif N. et Macé E., Les féministes et le garçon arabe, Paris, L'Aube, 2004.

${ }^{58}$ De Closets F., La Grande Manip, Paris, Le Seuil, 1990. Esse livro põe em dúvida o discurso moral de SOSracismo, acusado de produzir clivagens ideológicas mais do que ajudar a resolver problemas concretos.

59 Juhem P., SOS-racisme, histoire d'une mobilisation " apolitique ". Contribution à une analyse des transformations des représentations politiques après 1981, Thèse de doctorat (Dir: Bernard Lacroix), Paris X Nanterre, 2002. Pierre-André Taguieff, muito tempo próximo de SOS-racismo, explicita assim sua distância após a guerra atacando "o antirracismo diferencialista" que fará o jogo da extrema direita. Taguieff P.-A., Face au racisme, Paris, La Découverte, 1991, notamment tome 2, PP. 13-63.
} 
políticos. A constatação central na origem dessa articulação consiste em dizer que a exclusão sobretudo social produz o racismo. A esse respeito, os bairros populares das periferias onde a imigração é fortemente representada são percebidos como o berço do racismo, decorrente da manifestação do sentimento de abandono, de desamparo das populações mais despossuídas. Fenômeno que a enquete de Michel Wieviorka sobre a França racista, feita no início dos anos 1990, nuançou amplamente, ao mostrar que o racismo se associa menos às situações de exclusão social do que a grandes inquietudes culturais, assim como a medos identitários ${ }^{60}$.

Ao final dos anos 1990, essa perspectiva se reforça por meio de diversas abordagens que põem em destaque a produção do racismo no centro da sociedade. Do lado dos estudos das ciências sociais, a enquete realizada por Philipe Bataille sobre o mundo do trabalho revelou, sobretudo, que as discriminações raciais atingem o conjunto da sociedade e se traduzem por práticas e mecanismos institucionalizados que ocorrem no quadro da organização do trabalho ${ }^{61}$. No plano associativo, várias iniciativas testemunham uma vontade de pegar no ato os comportamentos discriminatórios. As campanhas de testing ${ }^{62}$, organizadas pelo SOS racismo desde 1999, mostram uma ação mais engajada junto às vítimas e os obstáculos que elas encontram em diversas domínios (emprego, alojamento, lazer). Em 2001, O MRAP abriu cerca de cinquenta locais de assistência para encorajar as vítimas e as testemunhas de discriminação a reagirem e a iniciarem processos ${ }^{63}$. Afirmações racistas proferidas numa altercação entre vizinhos, numa entrevista de recrutamento, entre colegas, recusa de abertura de conta bancária, recusa de emprego, dúvida ou certeza de ser discriminado, são casos que assinalam a extensão e a banalidade desses fenômenos no cotidiano.

Essa leitura do racismo, apoiando-se na realidade das discriminações raciais, ou seja, no tratamento desfavorável sofrido por uma pessoa ou por um grupo em razão de sua origem real ou suposta, de sua aparência ou ainda do seu nome estrangeiro, amplia consideravelmente o reconhecimento do fenômeno que ultrapassa desde então o

\footnotetext{
${ }^{60}$ Wieviorka M., La France raciste, Paris, Le Seuil, 1992.

${ }^{61}$ Bataille P., Le racisme au travail, Paris, La Découverte, 1998.

${ }^{62}$ A técnica vem dos Estados Unidos e da Grã-Bretanha, e consiste em apresentar dois candidatos de faces diferentes, mas com formação, perfis e estilos similares.

63 Uma dezena de entrevistas coletadas nesse quadro pode ser consultada no site da associação: www.discriminations-racistes.org/2_victime/recit.htm.
} 
contexto dos bairros desfavorecidos, assim como o campo de suas formas mais flagrantes, tais como o insulto ou a violência física. É nesse contexto que a ação pública, amplamente influenciada pela agenda da União Europeia ${ }^{64}$, implementou uma política específica de luta contra as discriminações raciais com o objetivo de "deslocar o foco de uma reflexão sobre as carências dos candidatos para a integração para uma reflexão sobre as durezas da sociedade de acolhimento"65. Dito de outro modo, de uma política exclusivamente centrada na integração, ou seja, na passagem do "exterior" ao "interior" da sociedade, o debate se desloca para o próprio funcionamento da sociedade ${ }^{66}$.

A ajuda às vítimas se torna portanto um dos eixos principais do programa de luta contra as discriminações. Um grupo de estudos (o Grupo de Estudos e de Luta contra as Discriminações, GELD) e um dispositivo são previstos para esse fim. Em 1999, são criadas as Comissões Departamentais de Acesso à Cidadania (CODAC). Implantadas em cada prefeitura e compostas por representantes ao mesmo tempo institucionais e associativos, sua missão consiste num primeiro momento em registrar os problemas específicos encontrados pelos jovens oriundos da imigração e de modo geral pelo conjunto das pessoas em dificuldade nas grandes políticas contratuais do Estado, como os empregos para jovens. Tornando-se em seguida o correspondente departamental do 114, plataforma telefônica nacional gratuita, implantada em maio de 2000, as comissões departamentais se constituem como "um lugar de escuta, de reflexão, de impulso e de implementação das ações destinadas a lutar contra as discriminações" ${ }^{67}$.

É nesse quadro que uma mutação maior se verifica em um combate contra o racismo. De um papel ainda muito impregnado pelo tema da integração e ancorado em ações de sensibilização, passa-se na verdade agora a uma implicação mais próxima dos

\footnotetext{
641997 foi proclamado o "ano europeu contra o racismo", em aplicação ao artigo 13 do Tratado de Amsterdã que encoraja o Conselho da União Europeia a tomar "medidas necessárias para combater toda discriminação fundada no sexo, na raça ou na origem étnica, na religião ou nas convicções, num handicap, na idade ou na orientação sexual". Duas diretivas foram apresentadas à Comissão de 25 de novembro de 1999. Uma delas convida sobretudo os Estados Unidos a pôr em prática um ou vários organismos de promoção da igualdade de tratamento afim de apoiar e ajudar as vítimas em seus procedimentos.

${ }^{65}$ Belorgey J.-M., Lutter contre les discriminations, Paris, Ministère de l'Emploi et de la solidarité, 1999. Observe-se que o termo «sociedade de acolhimento» empregado aqui ainda explicita a tendência do discurso político para encerrar os imigrados e seus descendentes, frequentemente cidadãos franceses, na diferença.

${ }^{66}$ Wieviorka M., « Faut-il en finir avec la notion d'intégration? », Les Cahiers de la sécurité intérieure, $n^{\circ} 45$, 2001, pp. 9-20.

${ }^{67}$ Circular do Primeiro Ministro de 02 de maio de 2000.
} 
indivíduos envolvidos. O dispositivo de ajuda direta às vítimas abre caminho a uma forma inédita de reconhecimento individual do racismo pelas autoridades públicas. Concretamente, os atendentes do número verde 114 são encarregados de preencher fichas de chamada que permitem identificar quem chamou e relacionar os fatos discriminatórios a fim de transmiti-los à CODAC mais próxima. No local, um ou vários atendentes deve orientar e acompanhar as vítimas em seus procedimentos.

O desenvolvimento da discriminação positiva no Brasil: prolongamento ou contradição da democracia racial?

Até meados dos anos 1990 no Brasil, raras são as vozes que se levantam para denunciar o racismo como elemento que estrutura certas relações sociais e práticas institucionais. Como sublinha Sergio Adorno, apenas alguns estudos demonstraram de fato as lógicas discriminatórias apresentadas pelas instituições. Por meio de sua análise do sistema penal, ele mostra, por exemplo, em que medida a cor da pele é um fator determinante nas diferenças de tratamento dos indivíduos pelo sistema judicial. Fica claro que $58 \%$ dos acusados negros foram presos em flagrante delito, contra $46 \%$ de acusados brancos. Ademais, $62 \%$ dos negros são defendidos por um advogado designado pelo Estado, para $39,5 \%$ dos brancos ${ }^{68}$.

Em meados dos anos 1990, aparecem progressivamente campanhas de sensibilização para lutar contra as manifestações cotidianas do racismo e das discriminações sociais. Nos imóveis e residências de alto padrão, denuncia-se, por exemplo, o fato de que os negros devam utilizar somente as entradas e os elevadores de serviço. Como apresenta um quadrinho do "Conselho de Desenvolvimento da Comunidade Negra" do Estado da Bahia ${ }^{69}$, os negros se veem às vezes proibidos de entrar em lugares públicos, como casas noturnas badaladas, e mais comumente em supermercados onde sãos frequentemente suspeitos de furto. Um negro visto à noite num bairro residencial por uma patrulha da polícia é imediatamente interpelado para

\footnotetext{
68 Adorno S., "Racial Discrimination and Criminal Justice in São Paulo », in Reichmann R. (dir.), Race in contemporary Brazil. From Indifference to inequality, University Park, The Pennsylvania State University Press, 1999, pp. 123-137.

${ }^{69}$ Secretaria de justiça e direitos humanos, Conselho de Desenvolvimento da Comunidade Negra, A lei e o Direito Do Negro, vol. I, Salvador, novembro de 1994.
} 
verificação da identidade e interrogado sobre o motivo da sua presença nesse local, pois supõe-se que residem somente nas favelas e nas periferias das cidades.

Enquanto as políticas públicas francesas implementam uma lógica defensiva para lutar contra as discriminações, o Brasil desenvolve uma lógica contraofensiva por meio de medidas de discriminação positiva. Em 1995, o governo toma uma série de medidas em favor dos negros e mestiços. Trata-se ao mesmo tempo de valorizar essa população reconhecendo o papel desempenhado pelos negros na construção material e cultural do Brasil, e de colocar em prática políticas para garantir a todos a igualdade de acesso aos benefícios da cidadania. O dia 20 de novembro de 1995 é escolhido como "Dia da consciência negra", em homenagem a Zumbi, chefe negro do célebre Quilombo dos Palmares, assassinado pelas autoridades coloniais em 1695, alçado a herói nacional. Ao mesmo tempo, um grupo de trabalho interministerial é acionado para assegurar a representação da população negra no emprego, nas mídias (promoção de uma imagem apropriada dos negros nas mídias e nos programas culturais oficiais), na educação (promoção da não discriminação e da tolerância no sistema escolar, escolha de livros didáticos que valorizem, sem estereótipo nem discriminação, a história e os combates do povo negro na construção da nação brasileira), ou ainda na saúde ${ }^{70}$.

Essas medidas governamentais reforçam a ação das associações, em particular de mulheres, que lutam há muitos anos contra o racismo. Trata-se sobretudo de associações tais como Geledés, criada em 1988, e Fala Preta, criada em 1997, que articulam o tratamento de formas diversas de discriminação. As iniciativas permitem reunir, na mesma estrutura, as denúncias de opressões e discriminações abrangendo diferentes campos (violência doméstica, racismo, problemas de saúde). Essa perspectiva leva em consideração o acúmulo, e mesmo a experiência simultânea de vários tipos de discriminações sofridas por um mesmo indivíduo, o que lhe deixa uma margem maior de ação para se defender.

O trabalho dessas associações traduz, aliás, uma importante mudança nas organizações ligadas ao movimento negro. Anteriormente, essas últimas se concentravam essencialmente na elaboração de uma identidade negra específica. Ora, se

\footnotetext{
70 Comitê para a Eliminação das Discriminações Raciais (CERD), resenha analítica da $1157^{a}$ sessão: Bolívia, Brasil, CERD/C/SR.1157, 1996.
} 
a construção de uma identidade racial é sempre importante, existe um interesse crescente pelas desigualdades no domínio do emprego, da educação ou ainda da saúde.

Desde meados dos anos 1990, o Brasil não cessou de reforçar seu dispositivo de discriminação positiva no campo da educação. Assim, foi decidido que $10 \%$ das vagas nos estabelecimentos de ensino superior seriam reservadas aos jovens pertencentes a grupos vítimas de discriminação. Além disso, os programas de ensino do Estado de São Paulo introduziram uma seção que trata da questão do racismo. Igualmente, os programas de estudos escolares e universitários do país inseriram uma disciplina intitulada "História e cultura da África”, que permite sublinhar o lugar que ocupam as culturas africanas na edificação da sociedade brasileira. Existe desde então no Brasil um sistema segundo o qual $40 \%$ das pessoas que participam das atividades realizadas pelas mídias estatais devem ser de negras. O objetivo é igualmente mostrar nas mídias a importância do papel dos negros na edificação da sociedade brasileira ${ }^{71}$.

Em nível internacional, a participação do Brasil no projeto não governamental - no qual várias autoridades brasileiras participaram - Beyond racism, em colaboração com os Estados Unidos e a África do Sul, mostra a vontade de promover o reconhecimento do racismo e das discriminações raciais ${ }^{72}$. Essa iniciativa deu possibilitou um trabalho estatístico que revela, área por área, o peso da variável racial nas desigualdades entre indivíduos. Fica-se sabendo, por exemplo, que quase $26 \%$ dos negros, comparativamente a $16 \%$ dos brancos, ganham menos que o salário mínimo, enquanto $1 \%$ dos negros ganha 10 vezes o salário mínimo, contra $4 \%$ de brancos. Dois terços das crianças afrodescendentes (African Brazilian) têm acesso à educação básica, comparativamente a $85 \%$ das crianças brancas. Registram-se desproporções igualmente flagrantes acerca do desemprego, da saúde, da expectativa de vida, da representação nas mídias, que refletem claramente as desigualdades que atingem a população negra.

Da mesma forma, a conferência mundial contra o racismo, que aconteceu em Durban em 2001, deu um novo impulso às políticas de discriminação positiva. Em resposta

\footnotetext{
${ }^{71}$ Nações Unidas, 10 de junho de 1998, Conselho Econômico e Social. Documento de trabalho comum sobre o artigo 7 da Convenção Internacional sobre a eliminação de todas as formas de discriminação racial. Estabelecido pelos senhores José Bengoa, Ivan Garvalov e Mustafa Mehedi e pela senhora Shanti Sadiq Ali.

${ }^{72}$ Comparative Human Relations Initiative, The Southern Education Foundation, Beyond Racism, Embracing an interdependent future. Brazil, South Africa, The United States, Three nations at the crossroads, Atlanta, The Southern Education Foundation, 2000.
} 
às expectativas formuladas nesse evento, o Ministro do Desenvolvimento Agrário anunciou um "Programa de discriminação positiva para os homens e as mulheres negros". Essa ação visa sobretudo reduzir as desigualdades entre os funcionários e os beneficiários da reforma agrária e da agricultura familiar. Isso implica entre outros a implantação de cotas para a participação dos homens e das mulheres negros nas posições administrativas. Ademais, a Assembleia Legislativa do Rio de Janeiro anunciou que $40 \%$ dos ingressos na universidade serão reservados aos negros e aos mestiços ${ }^{73}$.

Mais recentemente, desde maio de 2003, um escritório da Secretaria Especial para a Promoção da Igualdade Racial foi encarregado de coordenar as atividades desenvolvidas pelo Governo para combater a discriminação racial e promover a igualdade racial, inclusive em matéria de emprego, cultura, educação e saúde. Essa instância precisou que a política de discriminação positiva levava em conta as pessoas de ascendência africana e provocou a nomeação do primeiro juiz negro para o STF.

A aplicação de políticas de discriminação positiva no Brasil dá uma nova densidade ao debate sobre a questão racial. Após ter apostado numa lógica repressiva e defensiva para conter o racismo, o Estado brasileiro, mostrando vontade política para corrigir diretamente os efeitos das discriminações raciais, assume uma espécie de responsabilidade em seus mecanismos de produção. Cuidando diretamente da representação e da integração das populações negras e mestiças nas instituições, ele sublinha que a ausência dessas políticas participa dos mecanismos discriminatórios em prática na sociedade.

Essa lógica contraofensiva desencadeou uma polêmica sobre o questionamento que ela introduz sobre a democracia racial. Para César Benjamin, a discriminação positiva

\footnotetext{
${ }^{73}$ Human Rights in Brazil, The Global Justice Center Annual Report, estudo orientado por Sandra Carvalho, 2002. Notemos entretanto que está longe de introduzir práticas sistemáticas no interior das universidades. Cada universidade é autônoma e decide sua política própria. Uma polêmica explodiu recentemente na Universidade de Brasília em relação à política das cotas para os estudantes de cor. Entre as primeiras apostas está a da definição da cor. É sobre os fenótipos que caracterizam as pessoas negras que se apoiam as universidades. Os candidatos selecionados pelo sistema de cotas devem comprovar ter traços que simbolizam a raça (a cor da pele, os cabelos, o nariz, a boca). A Universidade de Brasília previu uma fase de verificação das declarações de cor feitas pelos candidatos. As fotos são examinadas por uma comissão especialmente indicada para esse fim. Diante da mestiçagem complexa da população brasileira, essa medida engendra sem dúvida importantes controversas sobre as homologações que saem dos pareceres da comissão (Correio Braziliense, 3 de janeiro de 2005). Essas informações foram tiradas do site http://www.observa.ifcs.ufri/.br/sobre/ (site do observatório das ações de discriminações positivas no ensino universitário).
} 
é uma espécie de desrazão em vista do continuum de cor da população brasileira. Segundo ele, "constituir uma identidade baseada na raça é particularmente reacionário"74. Portanto, uma política de cotas em favor dos negros constitui um anacronismo. O principal argumento dos detratores da discriminação positiva se baseia no perigo do uso de uma categoria biológica por políticas públicas em detrimento da ideia de democracia racial. Em outras palavras, as cotas revitalizariam a noção de raça, que a narrativa da democracia racial tinha conseguido fundir num mito, supostamente mais efetivo do que todavia o é. Peter Fry vai mais ou menos na mesma direção ao sublinhar que embora o mito da democracia racial pareça constantemente neutralizar a consciência das discriminações raciais e do racismo, é crucial dissociar a vontade de minimizar a pertinência da ideia de raça na vida social (ao combater o racismo no local de trabalho, na escola, nos tribunais) da de elaboração de políticas que se fundam na ideia de raça como critério para a distribuição dos recursos públicos. Segundo ele, o discurso da ação afirmativa leva a reconhecer a existência das raças. Sueli Carneiro, presidente da associação Geledés, insiste, por sua vez, no imperativo que representam essas políticas num país em que o negro não pode ser reduzido a uma realidade estatística e deixado na expectativa de uma ascensão social improvável. Ela lembra a esse respeito que apenas $2 \%$ da população negra acessa a universidade ${ }^{75}$.

A necessidade da discriminação positiva revela uma parcela das ciladas da democracia racial. O Brasil certamente desconstruiu o tabu em torno da questão racial que atenua amplamente a imagem idílica da harmonia racial que ele ostentava ${ }^{76}$. Resta saber como o país pode encontra um modus vivendi para aplicar essa política a partir do continuum de cor de sua população.

Ao desenvolver uma lógica de repressão dos atos e dos comportamentos racistas, o Brasil e a França resistiram por muito tempo a enfrentar a questão do racismo. Antes de ser reconhecido como uma experiência vivida, como um atentado à identidade de pessoas singulares ou de grupos, o fenômeno foi sobretudo apreendido nesses dois países a partir de seus mecanismos de produção, de fontes sociais suscetíveis de alimentá-lo, o que frequentemente leva a negligenciar suas consequências na vida dos

\footnotetext{
${ }^{74}$ Revista Caros Amigos, junho de 2002. Tradução: Georges da Costa, outubro de 2002.

${ }^{75}$ Revista Caros Amigos, julho de 2002. Tradução: Georges da Costa, setembro de 2002.

${ }^{76}$ «Race in Brazil: Out of Eden », The Economist, 3 de julho de 2003.
} 
indivíduos. Essa perspectiva não somente contornou a responsabilidade do Estado, mas igualmente privou a luta contra o racismo de ações políticas concretas permitindo atacar de frente o fenômeno.

A segunda metade dos anos 1990 marca, entretanto, uma virada nos dois países ao desenvolverem políticas de ajuda direta às vítimas. Tanto no Brasil como na França, esses processos revelam mais a ação do Estado do que a mobilização das populações vítimas que se reconhecem mais ou menos nos dispositivos postos em prática.

A França desenvolveu nesses últimos anos um dispositivo institucional encarregado de receber as queixas das vítimas. O fato de levar em conta a dimensão racial, étnica ou cultural verbalizada pelos indivíduos transtornou e ultrapassou as definições habituais do racismo, frequentemente fundadas em discursos e argumentos racistas. O principal desafio que levantam essas narrativas no quadro de um tratamento institucional personalizado das discriminações raciais é a articulação que se faz entre suas concepções objetivas e subjetivas, ou entre suas representações coletivas, e a sua vivência. A esse respeito, o mérito de um dispositivo tal como o número de ligação gratuito 114 foi o de pôr em evidência as linhas de tensão entre esses dois elementos que frequentemente tiveram dificuldade em se articular no quadro das instituições ${ }^{77}$. Esse elemento mostra que a luta contra o racismo não se limita a reforçar as sanções, mas sobretudo a poder aplicá-las. A apresentação de queixas ao Ministério Público continua sendo rara, em parte devido à decisão das instituições em questão (polícia, judiciário) que julgam inútil tratar o caso, mas igualmente devido à reticência dos indivíduos a iniciar um processo longo, custoso e julgado por vezes muito pesado em vista das expectativas das vítimas. A criação recente da Alta Autoridade de Luta contra as Discriminações e pela Igualdade (AALDI) marca uma nova virada no processo de institucionalização da luta contra o racismo ${ }^{78}$.

\footnotetext{
77 Poli A., «Le renouvellement de l'action publique contre le racisme dans le cadre du dispositif 114/Codac ", in Cossée C., Lada E., Rigoni I. (dir.), Faire figure d'étranger. Regards croisés sur la production de l'altérité, Paris, Armand Colin, 2004, pp. 211-224.

${ }^{78}$ A lei de 30 de dezembro de 2004 estabelece esta nova autoridade. Acerca dos casos de discriminação, a autoridade poderá ser acionada diretamente pela vítima ou por intermédio de um parlamentar ou de um representante francês no Parlamento europeu, ou ainda ser acionada conjuntamente pela vítima e uma associação. Enfim, a autoridade poderá igualmente se autoacionar, se uma vítima identificada não se opuser. O autoacionamento é particularmente importante em matéria de discriminação indireta, em que práticas coletivas que excluem grupos de pessoas podem ser reveladas, sem que uma intenção delituosa
} 
Por sua vez, o Brasil leva adiante há alguns anos uma política de discriminação positiva $^{79}$. Essa decisão dá uma visibilidade maior à problemática racial, adormecida pela força da narrativa da democracia racial, e coloca a questão central da designação e da localização dos indivíduos aos quais se endereça essa medida.

A multiplicação e o reforço das afirmações culturais, étnicas, religiosas observáveis no interior dessas sociedades reivindicam igualmente uma nova abordagem do racismo. No Brasil, essa tendência procede da eclosão de uma identidade afro-brasileira que força a rever a constatação presente por muito tempo da falta, e até mesmo da ausência, de mobilização dos afro-brasileiros ${ }^{80}$. Por isso, como se articularão as lógicas de desenvolvimento da discriminação positiva e as da afirmação identitária? Na França, uma parte das denúncias atuais pelas quais transitam a afirmação das identidades póscoloniais, assim como as reivindicações construídas em torno da memória do tráfico de escravos, lança um desafio às políticas de reconhecimento e abre um imenso espaço para reconsiderar a relação entre o racismo vivido no presente e no passado. As variantes do fenômeno não devem somente ser repensadas à luz da história, da memória, mas também do ponto de vista da dimensão espacial que elas trazem à baila. Em que medida elas devem ser pensadas nas fronteiras do Estado-nação? Posicionar-se como vítima, ou reconhecer-se no ódio de tal ou tal grupo (ou os dois), pode alimentar-se da identificação com vidas, com experiências - ou pelo menos com a ideia que se faz delas - longe das fronteiras do país onde se vive. Muitas vezes, o retorno do antissemitismo ${ }^{81}$ na sociedade francesa foi relacionado às formas de identificação e às opiniões ligadas ao conflito entre Israel e Palestina. Assim, em que medida o racismo é influenciado, inspirado, mas também contornado ou reinterpretado por lógicas globais?

\footnotetext{
possa ser individuada e sem que se possa identificar precisamente as vítimas.

${ }^{79}$ Adesky J. (d'), Racismes et antiracismes au Brésil, Paris, L'Harmattan, 2001.

${ }^{80}$ Sobre esse movimento de reivindicação da identidade afro-brasileira, ver em especial o trabalho de conclusão de curso de sociologia de Fabien Liquori, La réafricanisation de la culture de Bahia par le candomblé, (Directeur: Angelina Peralva), Université Toulouse le Mirail, 2002. Ver também Roth Gordon J., Hip-Hop Brasileiro: Brazilian Youth and Alternative Black consciousness Movements, paper apresentado na reunião anual da American Anthropology Association, Chicago, 1999.

${ }^{81}$ Wieviorka M. et al., La tentation antisémite. La haine des Juifs dans la France d'aujourd'hui, Paris, Robert Laffont, 2005.
} 
As tentativas para reconectar as dimensões objetivas e subjetivas da luta contra o racismo e as discriminações raciais transformam o espaço de conflitos voltado ao reconhecimento desses fenômenos. As políticas de ajuda direta às vítimas que se observa na França e no Brasil - quer tomem a forma de um dispositivo de tratamento das queixas, quer de uma política de discriminação positiva - produzem, revelam e põem em circulação múltiplas versões do fato de ser discriminado, as quais por vezes se colidem, se opõem ou ainda concorrem entre si. Essa mutação lança novos desafios ao tratamento do racismo nesses dois países, como o de pensar conjuntamente diferentes tipos de experiência vivida do racismo e de oferecer respostas. A necessidade de identificar as vítimas - cuja luta contra o racismo parece ultrapassada limitando-se a uma condenação moral -, que transtorna as lógicas de pertencimento a um grupo, enfraquece, na verdade, a concepção unificada do combate ao racismo e levanta a questão das articulações entre o registro da denúncia e o da afirmação das diferenças.

\section{Referências}

«Race in Brazil: Out of Eden », The Economist, 3 de julho de 2003. Disponível em http://www.economist.com/node/1897546 SEM AUTOR

ADORNO, Sérgio, «Racial Discrimination and Criminal Justice in São Paulo », in REICHMANN, Rebecca Lynn. (dir.), Race in contemporary Brazil. From Indifference to inequality, University Park, The Pennsylvania State University Press, 1999, pp. 123-137.

AGIER, Michel, « Ethnopolitique. Racisme, statuts et mouvement noir à Bahia », Cahiers d'Etudes Africaines, n¹25, 1992, pp. 53-81;

AGIER, Michel, Anthropologie du carnaval. La ville, la fête et l'Afrique à Bahia, Marseille, éditions Parenthèses/IRD, 2000, p. 228.

ANDRADE, Mário de, Macounaima, Paris, Stock/Unesco/Allca XX, 1996 (1928).

AZEVEDO, Célia Maria Marinho de. « Abolicionismo e memória das relações raciais », Estudos Afro-Asiáticos, 26, 1994, pp. 5-20.

BASTIDE, Roger, « Les relations raciales au Brésil », Bulletin International des Sciences Sociales, Unesco, vol. 9, $n^{\circ} 4$, 1957, pp. 525-543. 
BASTIDE, Roger, FERNANDES, Florestan, Relações Raciais entre Negros e Brancos em São Paulo, São Paulo, Unesco-Anhembi, 1955.

BATAILLE, Philippe, Le racisme au travail, Paris, La Découverte, 1998.

BELORGEY, Jean-Michel, Lutter contre les discriminations, Paris, Ministère de l'Emploi et de la solidarité, 1999.

BENNASSAR, Bartolomé, MARIN, R i c h a r d , Histoire du Brésil, 1500-2000, Paris, Fayard, 2000.

BOLI, John and THOMAS, George M. « World Culture in the World Polity: A Century of International Non-Governmental Organisation », American Sociological Review, $\mathrm{n}^{\circ}$ 62, 1997, pp. 171-190.

BURDICK, John, « The lost constituency of Brazil's black movements », Latin American Perspectives, 25 (1), 1998, pp. 136-155.

BURNS, Bradford Edward., A History of Brazil, $3{ }^{\text {ème }}$ édition, New York, Columbia University Press, 1993.

Comitê para a Eliminação das Discriminações Raciais (CERD), resenha analítica da $1157^{\text {a }}$ sessão: Bolívia, Brasil, CERD/C/SR.1157, 1996.

Comparative Human Relations Initiative, The Southern Education Foundation, Beyond Racism, Embracing an interdependent future. Brazil, South Africa, The United States, Three nations at the crossroads, Atlanta, The Southern Education Foundation, 2000.

D'ADESKY, Jacques Edgard, Racismes et antiracismes au Brésil, Paris, L'Harmattan, 2001.

DE CLOSETS, François, La Grande Manip, Paris, Le Seuil, 1990.

DUBET, François, La Galère: jeunes en survie, Paris, Fayard, 1987.

DUBET, François, Lapeyronnie D., Les quartiers d'exil, Paris, Seuil, 1992.

ECCLES, Peter J., Culpados até prova em contrário: os negros, a lei e os direitos humanos no Brasil, Estudos Afro-asiáticos, 1991.

Edição atualizada em 1994 [texto de 5 de outubro de 1988 modificado pelas emendas $n^{\circ}$ $1 / 92$ a 4/93 e n $1 / 94$ à 6/94], tradução francesa de J. Villemain, atualizada J.F. Cleaver, Brasília, Senado Federal, 1994.

FEAGIN, Joseph R., SIKES, Melvin, Living with racism, Boston, Beacon, 1994, pp. 15-17

FLORESTAN, Fernandes, A Integração do Negro na Sociedade de Classes, 3 a edição, São Paulo, Ática, 1978; FLORESTAN, Fernandes, The Negro in Brazilian Society, New York, Columbia University Press, 1969. 
FREYRE, Gilberto, Casa Grande e Senzala: formação da Família Brasileira sob o regime da economia patriarcal, Rio de Janeiro, Maia \& Schmidt, 1933.

GASTAUT, Yvan , “'Sommes nous racistes ?' Evolution d'une question angoissante dans l'espace public français », Migrations Société, vol. 9, n 49, janvier-février 1997, pp. 53-66.

GASTAUT, Yvan, «La flambée raciste de 1973 en France », Revue Européenne des Migrations Internationales, vol. 9, n², 1993, pp. 61-75.

GASTAUT, Yvan, «Le racisme anti-maghrébin et les séquelles de la guerre d'Algérie », Hommes et Migrations, $n^{\circ} 1174$, mars 1994, pp. 35-42.

GASTAUT, Yvan. « Le racisme anti-maghrébin et les séquelles de la guerre d'Algérie », Hommes et Migrations, $n^{\circ} 1174$, mars 1994, pp. 35-42.

GUÉNIF-SOUILAMAS, Nacira et MACÉ, Éric, Les féministes et le garçon arabe, Paris, L'Aube, 2004.

Guimarães A.-S.-A., « Intelectuais negros e formas de integração nacional », Estudos Avançados, vol. 18, $n^{\circ}$ 50, 2004, pp. 271-284.

Guimarães A.-S.-A., Racial Inequalities, Black Protest and Public Policies in Brazil, Paper prepared for the United Nations Research Institute for Social Development (UNRISD) Conference on Racism and Public Policy, septembre 2001, Durban, Afrique du Sud.

Guimarães A.-S.-A., Racismo e Anti-racismo no Brasil, São Paulo, Editora 34, 1999.

GUIMARÃES, Antonio Sérgio Alfredo, « Démocratie raciale », Cahiers du Brésil Contemporain, Paris, $n^{\circ}$ 49-50, 2002, pp. 11-38.

HANCHARD, Michael George, Orpheus and Power: the movimento negro of Rio de Janeiro and São Paulo, Brazil, 1945-1988, Princeton, Princeton University Press, 1994;

Hasenbalg Carlos, Discriminação e desigualdades no Brasil, Rio de Janeiro, Graal, 1979; SILVA, Nelson do Valle, "Updating the cost of not being white », in FONTAINE, Michel (dir.), Race, class and power in Brazil, Los Angeles, University of California Press, 1985, pp. 42-55.

Human Rights in Brazil, The Global Justice Center Annual Report, estudo orientado por Sandra Carvalho, 2002.

JUHEM, Philippe, SOS-racisme, histoire d'une mobilisation « apolitique ». Contribution à une analyse des transformations des représentations politiques après 1981, Thèse de doctorat (Dir: Bernard Lacroix), Paris X Nanterre, 2002.

LIQUORI, Fabien, La réafricanisation de la culture de Bahia par le candomblé, (Directeur: Angelina Peralva), Université Toulouse le Mirail, 2002. 
M'scope, “Image de l'immigration dans les médias", dossier, 1993, pp. 33-44. Para uma leitura crítica sobre a acumulação das denuncias feitas ao jovem árabe de periferia.

MAIO, Marcos Chor. "O Projeto Unesco e A Agenda das Ciências Sociais no Brasil dos Anos 40 e 50 ", Revista Brasileira de Ciências Sociais, vol. 14, n 41, 1999, pp. 141-158.

Nações Unidas, 10 de junho de 1998, Conselho Econômico e Social. Documento de trabalho comum sobre o artigo 7 da Convenção Internacional sobre a eliminação de todas as formas de discriminação racial. Estabelecido pelos senhores José Bengoa, Ivan Garvalov e Mustafa Mehedi e pela senhora Shanti Sadiq Ali.

NOBLES, Melissa, Shades of Citizenship: Race and the Census in Modern Politics, Stanford, Stanford University Press, 2000.

NOGUEIRA, Oracy, Tanto Preto Quanto Branco: Estudos de Relações Raciais, São Paulo, T.A. Queiroz, 1985.

PARK, Robert Ezra, Race and Culture, New York, The Free Press, 1950.

PERALVA, Angelina, MACÉ, Éric, Médias et violences urbaines. Débats politiques et construction journalistique, Paris, La Documentation française, 2002.

PERALVA, Angelina, Violence et démocratie. Le paradoxe brésilien, Paris, Balland, 2001, p. 33.

PERALVA, Angelina, Violence et démocratie. Le paradoxe brésilien, op. cit., p. 53.

PEREIRA DE QUEIROZ, Maria Isaura, «Identidade cultural, identidade nacional no Brasil, Tempo Social », Revista de Sociologia da USP, vol. 1, n 1, 1989.

PIERSON, Donald., Negroes in Brazil: A Study of Race Contact in Brazil, Carbondale, Southern Illinois University Press, 1942.

POLI, Alexandra, « Le renouvellement de l'action publique contre le racisme dans le cadre du dispositif 114/Codac », in COSSEE Claire, LADA Emmanuelle, RIGONI Isabelle (dir.), Faire figure d'étranger. Regards croisés sur la production de l'altérité, Paris, Armand Colin, 2004, pp. 211-224.

RAISSIGUIER, Catherine, "Gender, Race and Exclusion: A New look at the French Republican Tradition”, International Feminist Journal of Politics, vol. 1, n³, 1999, pp. 435457.

Revista Caros Amigos, julho de 2002. Tradução: Georges da Costa, setembro de 2002.

Revista Caros Amigos, junho de 2002. Tradução: Georges da Costa, outubro de 2002.

RODRIGUES, Nelson Falcão, L’ange noir, Paris, Collection des Quatre-vents, 1988 (1947). 
ROTH-GORDON, Jennifer, Hip-Hop Brasileiro: Brazilian Youth and Alternative Black consciousness Movements, paper apresentado na reunião anual da American Anthropology Association, Chicago, 1999.

SANSONE, Lívio, From Africa to Afro, Use and Abuse of Africa in Brazil, the South-South Exchange Programme for Research on the History of Development (SEPHIS) and the Council for the Development of Social Science Research in Africa (CODESRIA), Amsterdam/Dakar, 1999;

Secretaria de justiça e direitos humanos, Conselho de Desenvolvimento da Comunidade Negra, A lei e o Direito Do Negro, vol. I, Salvador, novembro de 1994.

SHERIFF, Robin E. « Exposing Silence as Cultural Censorship: A Brazilian Case », American Anthropologist, vol. 102, $\mathrm{n}^{\circ}$ 1, 2000, pp. 114-132.

SHERIFF, Robin E. Dreaming Equality: Color, Race, and Racism in Urban Brazil, New Brunswick, Rutgers University Press, 2001, p. 142.

SKIDMORE, Thomas E., « Fact and Myth: discovering a racial problem in Brazil, São Paulo ", Instituto de Estudos Avançados, 1992.

STORA, Benjamin, Le transfert d'une mémoire. De « l'Algérie française » au racisme antiarabe, Paris, La découverte, 1999, p. 91.

TAGUIEFF, Pierre-André, Face au racisme, Paris, La Découverte, 1991, notamment tome 2, PP. 13-63.

TELLES, Edward E., LIM, Nelson, « Does it Matter Who Answers the Race Question?: Racial Classification and Income Inequality in Brazil », Demography, 35(4), 1998, pp. 465-474.

TELLES, Edward E., « Ethnic boundaries and political mobilisation among African Brazilians: comparisons with the US case », in HANCHARD, Michael George (dir.), Racial Politics in Contemporary Brazil, London, Duke University Press, 1999.

TWINE, France Winddance , « Mapping the terrain of Brazilian racism », Race and Class, vol. 38, n³, 1997, pp. 49-61.

VÉRAN, Jean-François, « Brésil: les découvertes du « quilombo ». La construction hétérogène d'une question nationale », Problèmes d'Amérique Latine, n 32, 1999.

Weber J., « Racisme pas d'âge », L’humanité, 17 octobre 1978.

WEIL, Patrick, La France et ses étrangers, l'aventure d'une politique de l'immigration, 1938-1991, Paris, Calmann-Lévy, 1991.

WIEVIORKA, Michel et al., La tentation antisémite. La haine des Juifs dans la France d'aujourd'hui, Paris, Robert Laffont, 2005. 
WIEVIORKA, Michel, « Faut-il en finir avec la notion d'intégration? », Les Cahiers de la sécurité intérieure, $\mathrm{n}^{\circ}$ 45, 2001, pp. 9-20.

WIEVIORKA, Michel, La France raciste, Paris, Le Seuil, 1992.

WINANT, Howard, « Rethinking Race in Brazil », Journal of Latin American Studies, $\mathrm{n}^{\circ}$ 24, 1992, pp. 173-192;

ZWEIG, Stefan, Le Brésil, terre d'avenir, Paris, L'Aube, 1992, (1941).

Recebido em: 20/05/2015 Aprovado em: 27/07/2015

Universidade do Estado de Santa Catarina - UDESC Programa de Pós-Graduação em Educação - PPGE Revista Linhas Volume 16 - Número 32 - Ano 2015 revistalinhas@gmail.com 